ORIGINAL

\title{
Population features of Hoplosternum littorale (Hancock, 1828) (Siluriformes, Callichthyidae) at Santo Anastacio Reservoir, Brazil
}

\author{
Características poblacionales de Hoplosternum littorale \\ (Hancock, 1828) (Siluriformes, Callichthyidae) en el reservorio \\ Santo Anastácio, Brazil
}

\author{
Francisco D. do Nascimento Chaves, ${ }^{1}$ Biól, Jorge I. Sánchez-Botero, ${ }^{1 *}$ Ph.D, \\ Danielle Sequeira Garcez, ${ }^{2}$ Ph.D, Vitor Cavalcanti dos Reis, ${ }^{1}$ Biól.
}

\begin{abstract}
${ }^{1}$ Universidade Federal do Ceará (UFC), Campus do Pici, Centro de Ciências, Depto. de Biologia - Bloco 906. Laboratório de Ecologia. CEP: 60455-970. Fortaleza / Ceará, Brasil. ${ }^{2}$ Universidade Federal do Ceará, Instituto de Ciências do Mar - LABOMAR. Av. da Abolição 3207, Meireles. CEP: 60165-081. Fortaleza/Ceará, Brasil. *Correspondencia: jisbar@gmail.com
\end{abstract}

Recibido: Septiembre de 2012; Aceptado: Agosto de 2013.

\begin{abstract}
Objective. The length-weight relationship and condition factor of fish are indicators of physiological well-being and may be related to reproduction and feeding periods. These attributes were evaluated for a population of Hoplosternum littorale sampled in the Santo Anastácio Reservoir (Fortaleza, Northeastern Brazil). Materials and methods. One hundred and fifty-five specimens were collected with gillnets between October 2009 and March 2010, and standard length (cm), total weight (g), sex and gonadal maturation stage were registered. Results. The observed length-weight relationship indicated negative allometric adjustment (2.72). Only seventy individuals were evaluated for the condition factor analysis, sexual determination and gonadal state classification. Condition factor values peaked in November and plummeted in February, no statistical differences in sex ratio $\left(X^{2}=13.683 ; p=0.057\right)$ were observed. Mature females were collected throughout the study period. Conclusions. The results indicate that the population of $\mathrm{H}$. littorale in the Santo Anastácio reservoir presents growth deficiency and changes in reproductive strategy in this hypereutrophic environment.
\end{abstract}

Key words: Brown hoplo, feeding, health, reproduction, reservoir (Source: AIMS).

\section{RESUMEN}

Objetivo. La relación peso-longitud y el factor de condición son indicadores del estado fisiológico en peces y pueden estar relacionados con la reproducción y los períodos de alimentación. Se realizó una evaluación de estos parámetros en Hoplosternum littorale en el reservorio Santo Anastácio, localizado en la ciudad de Fortaleza, Ceará, Brazil. Materiales y métodos. Se colectaron ciento-cincuenta y cinco muestras entre octubre de 2009 y marzo de 2010 utilizando redes de enmalle, y se registraron datos de longitud $(\mathrm{cm})$, peso total $(\mathrm{g})$, sexo y estado de maduración de órganos sexuales. Resultados. La relación peso-longitud presentó un crecimiento alométrico negativo (2.72). Para el análisis del factor de 
condición, la determinación del sexo y la clasificación del estado gonadal fueron analizados únicamente en 70 individuos. En noviembre se presentaron los valores mas altos del factor de condición, y los mas bajos se presentaron en febrero, sin diferencia en la proporción sexual $\left(X^{2}=13.683, p=0.057\right)$. Durante todo el tiempo del estudio se capturaron hembras maduras. Conclusiones. Los resultados indican que la especie $H$. littorale presenta deficiencias en el crecimiento y cambios en la estrategia reproductiva en el ambiente hipereutrófico que habitan.

Palabras clave: Alimentación, brown hoplo, reproducción, reservorio, salud (Fuente: AIMS).

\section{INTRODUCTION}

Fish populations in reservoirs consist of original river fauna, restructured by a range of environmental factors (1). The introduction of nutrients from agricultural, industrial and urban activities cause changes in water quality, which accelerates eutrophication processes and act directly on biotic integrity. This is reflected by several aspects of population dynamics, such as size, growth and reproduction parameters $(2,3)$.

The study of variables reflecting biological changes associated to growing eutrophication, such as fish length, weight and condition factor, are important in the restoration and management of aquatic environments. Fish weight and length data are used to determine the length and weight relationship, and to express the variation in expected weight for a given length, indicating general well-being, fat percentage and gonadal development $(3,4)$. Fish farmers use the lengthweight relationship as an indicator of well-being in fish populations, while the condition factor indicates the condition of individual specimens $(3,4)$. However, since fish growth is rarely isometric, the following equation is used to assess the condition factor $(\mathrm{K}): \mathrm{K}=\mathrm{W} / \mathrm{aL}^{\mathrm{b}}$ where $b$ is the angle of the linear regression, $W$ is fish weight in $\mathrm{g}$, $\mathrm{L}$ is fish length in centimeters, and $a$, is the coefficient of the length-weight relationship (4). The equation was used in this study as it makes it possible to analyze differences in length.

The condition factor is influenced by three basic parameters: the correlation with length (considered in the use of relative condition factor), the sampling method (effect of gillnets and location) and the environmental conditions such as food supply, parasitism and other biological interactions $(3,5)$. The condition factor is therefore a useful indicator of variation in the well-being of fish throughout their development (6).

The objective of this study was the analysis of a population of brown hoplo or tamoatá (regional common name of Hoplosternum littorale; Callichthyidae), a non-rare siluriform species from the Amazon basin (7). The tamoatá is a nocturnal bottom-dweller widely distributed on floodplains and in swamps, being reproductively adapted to these environments (8) and has the ability to survive in low dissolved oxygen environments $(7,9)$. Under conditions of hypoxic stress, the tamoatá may even use its intestinal epithelial cells for gas exchange (10).

The Santo Anastácio Reservoir suffers strong and frequent impacts from human activity (11), potentially affecting the growth and well-being of local fish populations. Biological, chemical, physical and morphological analyses indicate the reservoir is currently hypereutrophic (12). A temporary evaluation in the condition factor and weight-length relationship of the tamoatá in the Santo Anastácio reservoir can provide useful information of how these variables affect fish populations in hypereutrophic environments. This study describes related population features of $H$. littorale in a hypereutrophic environment.

\section{MATERIALS AND METHODS}

Studied area. The Santo Anastácio Reservoir is a small and shallow body of water located at $3^{\circ}$ $44^{\prime} 36^{\prime \prime} \mathrm{S}$ and $38^{\circ} 34^{\prime} 13^{\prime \prime} \mathrm{W}$, within the campus of the Federal University of Ceará (Universidade Federal do Ceará - UFC). It is part of the Maranguapinho watershed, which covers 86.8 $\mathrm{km}^{2}$ of coastal territory, in the municipality of Fortaleza (Ceará, Brazil). The ecosystem is in an advanced state of eutrophication, mainly due to the discharge of garbage and organic waste from nearby housing with little or no infrastructure $(12,13)$. The reservoir is currently used only for subsistence fishing (12).

The perimeter $(2.858 \mathrm{~m})$ and water volume $\left(316.760 \mathrm{~m}^{3}\right)$ of the Santo Anastácio Reservoir are relatively stable throughout the year; its depth ranges from 0.54 to $4.97 \mathrm{~m}$ (mean 2.29 $\mathrm{m}$ ). When the reservoir was built in 1918, the region was predominantly rural. Today half the area is residential (12). 
Sampling. Monthly samplings of $H$. littorale were performed from October 2009 to March 2010 using nine gillnets with graded mesh sizes ( 25 to $70 \mathrm{~mm}$ between opposite knots) measuring $20 \mathrm{~m}$ by $1.5 \mathrm{~m}\left(212.45 \mathrm{~m}^{2}\right)$. To cover both the limnetic zone and the lakeside, the nets were deployed perpendicularly to the shoreline for approximately three hours (from 8:00 to $11: 00$ ) and collected only once a day (11:00).

Data analysis. The sampled $H$. littorale $(n=155)$ were transported in ice boxes to the laboratory of Experimental Zoology of the Federal University of Ceará (UFC) for measurement of standard length $(\mathrm{cm})$ and total weight $(\mathrm{g})$. Length measures were organized into $1-\mathrm{cm}$ intervals, and the length-weight relationship was determined by estimating the value of the $a$-intercept and the $b$-slope. The determinations of sex and gonadal stage were made only in 70 individuals chosen randomly and based on the following classification: I=immature, II=maturing, $\mathrm{III}=$ mature, $\mathrm{IV}=$ spent, and their values for length and weight were used to calculate the relative condition factor $(K)$ using the formula $K=W / a L^{b}$ (3). For comparison purposes, $\mathrm{K}$ values and their respective variation coefficients were averaged monthly.

Each variable was averaged to prevent bias due to the small number of specimens collected during some periods. The chi-square test was used to detect differences in sex ratios (14). Individuals over $10 \mathrm{~cm}$ with mature or spent gonads were considered adults, as suggested by Hahn et al (15) and Hostache and Mol (7).

\section{RESULTS}

In this study, 155 specimens of $H$. littorale were captured. The standard length ranged from 12.8 to $19.2 \mathrm{~cm}$ (modal $=15.7 \mathrm{~cm}$ ), resulting in all specimens to be sexually mature.

The length-weight relationship yielded the following equation: $\mathrm{W}=0.0908 * \mathrm{~L}^{2.72}$, with an allometric negative adjustment $(2.72<3)$ (Figure 1$)$.

According to the analysis, the increase in weight was smaller than the increase in length. In other words, body weight did not increase as expected, as reflected by the condition factor values.

The $\mathrm{K}$ values obtained from the length-weight relationships varied little over time. The highest and lowest values were observed in November and February, respectively (Figure 2 ).

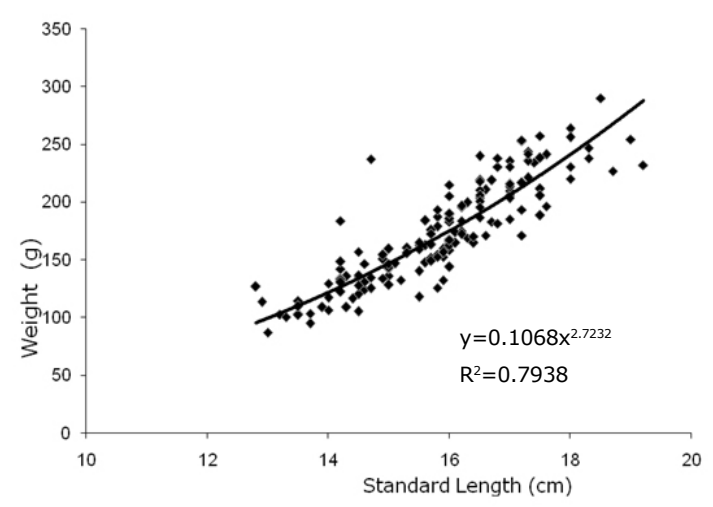

Figure 1. Relation between standard length and total weight of Hoplosternum littorale collected from the Santo Anastácio Reservoir (Ceará, Brazil).

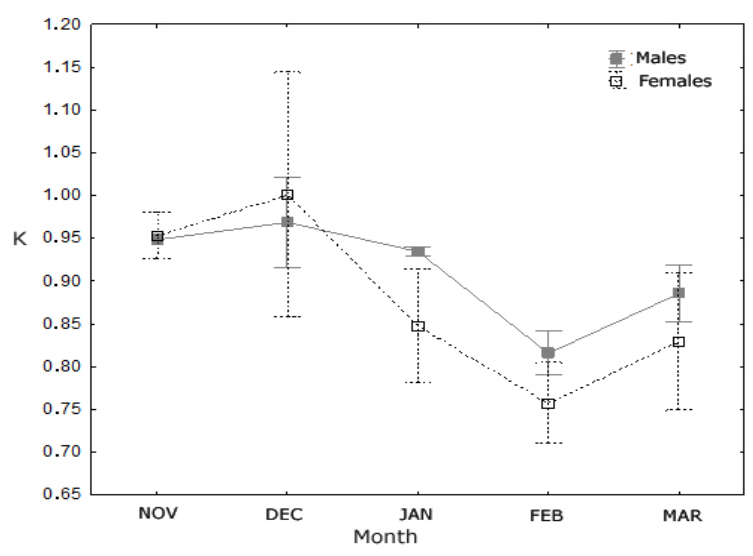

Figure 2. Sexual-specific average monthly condition factor values for Hoplosternum littorale in the Santo Anastácio Reservoir (Ceará, Brazil). The bars represent the standard deviation of each month.

Of the 70 individuals analyzed, 29 were females and 41 were males. The female/male sex ratio obtained from the chi-square test was 0.8: $1.2\left(X^{2}=13.683, p=0.057\right)$. Males in stage III predominated in December. Females in stage III were captured during the entire sampling period, but females in stage IV only in December (Table 1). No female had a standard length above $17.5 \mathrm{~cm}$.

Table 1. Sex ratio (\%) and gonad maturation values (number of individuals) per month in the samplings of Hoplosternum littorale in the Santo Anastácio Reservoir.

\begin{tabular}{|c|c|c|c|c|c|c|}
\hline \multirow{2}{*}{$\begin{array}{c}\text { Sex/stage } \\
(\%)\end{array}$} & \multicolumn{6}{|c|}{ Months } \\
\hline & Oct & Nov & Dec & Jan & Feb & Mar \\
\hline Female & 50 & 67 & 50 & 60 & 50 & 50 \\
\hline Male & 50 & 33 & 50 & 40 & 50 & 50 \\
\hline Immature & - & - & 5 & - & - & - \\
\hline Maturing & 4 & 1 & 1 & - & - & - \\
\hline Mature & 3 & 4 & 10 & 9 & 10 & 6 \\
\hline Spent & 2 & 4 & 6 & 1 & - & 4 \\
\hline
\end{tabular}


The equations determined $W=0.9022 * L^{1.85}$ for females, and $W=0.1518 * L^{2.53}$ for males. As an aid of the slope and intercept estimated from the length-weight relationship for males and females, we compared the monthly average (Figure 2). Both slopes indicated negative allometric growth: $\mathrm{b}=1.85$ for females, and $b=2.53$ for males $(\mathrm{b}<3)$.

\section{DISCUSSION}

The length-weight relationship and the condition factor have important applications in population studies, especially in the quantification of wellbeing and sexual maturity $(3,4)$. By comparison, Lima-Júnior and Goitein (16) conducted a population study on Pimelodus maculatus in the Piracicaba River in São Paulo State, Brazil. This ecosystem, like the Santo Anastácio reservoir, is hypereutrophic due to the discharge of domestic and industrial sewage. The $b$-slope (2.93) for $P$. maculatus was similar to that found in the present study suggesting polluted environments and/or extreme physical and chemical conditions are less than ideal for fish growth.

The association between low water quality in the Santo Anastácio Reservoir and reduced welfare of the tamoatá suggests that the hypereutrophic environment provided food of insufficient quantity and/or quality, especially in the conversion of ingested material into biomass. This is reflected directly in the condition factor of the species, despite its ability to adapt to hypoxic environments (aerial respiration) and its reproductive strategies (parental care and territoriality) (7).

In fish populations, sex ratios vary throughout their life cycle due to events that affect their sexuality, such as mortality, growth and sexspecific behavior (3). The latter seems to explain the sex ratio ( $F: M-0.8: 1.2)$ observed in our sample from the Santo Anastácio Reservoir. Most samplings were performed during the daytime, when the tamoatá is less active. However, during their reproductive period, when guarding the floating foam nest, the males become more active and territorial and develop a spine above the pectoral fin (seen in some individuals during this study), setting them apart from the females (7). The fact that the sampling period coincided with the mating season may explain why more males than females were captured.

In a study by Oliva-Paterna et al (17) the $b$-slope for tamoatá (2.84) collected in the Jurumirim Reservoir in Parapanema (São Paulo State, Brazil) was higher than the value found in the present study, but no mention was made of pollution. However, welfare, as reflected in the length-weight relationship, depends on other factors additional to water quality, including gonadal stage, food availability and conversion of ingested material $(4,17)$.

The average values of the allometric condition factor observed in this study followed the trend described by Hostache and Mol (7); which is, gonadal growth (hence, weight increase) toward the end of the dry season (November and December) in preparation for spawning after the beginning of the rainy season (18). The condition factor decreased in February (after spawning), possibly due to the allocation of energy reserves to mating activities $(6,16)$. The condition factor increased again following the onset of the rainy season in January when allochthonous food became available. This supports the hypothesis that $\mathrm{K}$ is subject to seasonal variation.

The tamoatá was not reported in previous studies as fish fauna for the Santo Anastácio reservoir $(19,20)$, perhaps because the population was small due to unfavorable environmental conditions in the past (10) or because the species was recently introduced from another ecosystem. High phosphorus levels $\left(57-130 \mathrm{mg} / \mathrm{m}^{3}\right.$ ) and low concentrations of dissolved oxygen (13) have favored the establishment of hardy species like the tamoatá. In fact, a section of the intestine of the tamoatá is capable of capturing oxygen for aerial respiration (21) with the help of a specific isohemoglobin for bimodal breathing (7). The tamoatá is a benthophagous scavenger with no need for clean water supply (15). Its reproduction is seasonal, with parental care performed by the male, increasing the chances of survival of the offspring (7). In other words, the tamoatá has a considerable local adaptive capacity for eutrophic environments (10), and it is an extremely popular fish in other Latin-American watersheds (7).

They sexually differed significantly compared to the length-weight relationship, possibly because of the greater demand for energy and food among females during the reproductive period (3). In fact, $K$ increased for females and decreased for males during the same period (December). The pattern is consistent with the beginning of the reproductive period $(7,22)$ when males release their gametes, thereby losing weight, and females become ovate due to fertilization, thereby increasing weight.

Typically, $H$. littorale has a seasonal reproductive cycle and spawns during the first month of the rainy season $(2,7,22)$. Thus, the presence of mature females throughout the entire sampling period may be associated to a change 
in the reproductive strategy of the species in response to environmental pressure, especially hypereutrophication. Nevertheless, our data is not sufficient to confirm a seasonal change in the reproductive period of the tamoatá in the Santo Anastácio Reservoir.

Another study compared the reproductive strategies of two species of the genus Corydoras (Callichthyidae). Mature females of the species Corydoras carlae were observed all year round, while mature females of the species Corydoras aeneus were only seen from July 1983 (though not in October) to February of 1984 (23). In a study on Aspidoras fuscoguttatus (Callichthyidae) by Araujo and Garutti (24), mating behavior was observed from August to March, with isolated peaks in October and March, but mature females were captured all year round. In other words, callichthyids display various reproductive strategies, reflecting key ecological factors in the embryonic period and throughout their life. These characteristics define the limits of distribution of the species, the biology of adult individuals and their ability to colonize new environments (25).

Winemiller (22) recognized three main reproductive strategies in South American freshwater fish, with the possibility of intermediate stages. Thus, fish of the genus Hoplosternum produce a small offspring by the end of the dry season (2). Based on our observations in the Santo Anastácio reservoir, the reproduction strategy of the tamoatá is seasonal with parental care, but, depending on circumstances, may be continuous (occurrence of mature females all year). This could be explained by changes in the reproductive pattern above (25). As explained by Lowe-McConnell (2), the life cycle of fish is regulated by seasonal changes in the environment, which affects feeding, migration, growth and breeding patterns.

The population features of $H$. littorale in a hypereutrophic reservoir in a semi-arid region in Northeastern Brazil presented allometric growth, decreased condition factor during the rainy season, and occurrence of mature females during the entire sampling period.

\section{Acknowledgements}

We would like to thank the Federal University of Ceará (UFC), specially Prof. Paulo Cascon, from Experimental Zoology Laboratory for lending us their equipment and work space; to the project PPP/FUNCAP (GPF 2153/85) for equipments and supplies; and to the staff of Aquatic Ecology Laboratory (Biology Department UFC), for field assistance.

\section{REFERENCES}

1. Antoniassi Luiz E, Carlos Gomes C, Antonio Agostinho A, Karen Bulla C. Influência de processos locais e regionais nas assembléias de peixes em reservatórios do Estado do Paraná, Brasil. Acta Sci Biol Sci 2003; 25(1):107-114.

2. Lowe-McConnell RH. Estudos ecológicos de comunidades de peixes tropicais. $1^{\mathrm{a}} \mathrm{Ed}$. São Paulo, Brasil: Editora da Universidade de São Paulo; 1999.

3. Martins EC, Caramaschi PE, Petry AC. Fator de condição: bases conceituais, aplicações e perspectivas de uso em Pesquisas ecológicas com peixes. Oecol Aust 2011; 15(2):249-274.

4. Froese R. Cube law, condition factor and weight-length relationships: history, metaanalysis and recommendations. J Appl Ichthyo 2006; 22:241-253.
5. Tavares-Dias M, Laterça Martins M, Ruas Moraes F, Nascimento Kronka S. Fator de condição e relação hepato e esplenossomática em teleósteos de água doce naturalmente parasitados. Acta Sci Biol Sci 2000; 22(2):533-537.

6. Lizama M de los AP, Ambrósio AM. Condition factor in nine species of fish of the Characidae family in the upper Paraná river floodplain, Brazil. Braz J Biol 2002; 62(1):113-124.

7. Hostache G, Mol JH. Reproductive biology of the neotropical armoured catfish Hoplosternum littorale (Siluriformes, Callichthyidae): a synthesis stressing the role of the floating bubble nest. Aquat Living Resour 1998; 11(3):173-185.

8. Winemiller KO. Patterns of variation in life history among South American fishes in seasonal environments. Oecol 1989; 81(2):225-241. 
9. Caldeira FN, Silva BF, Sá FS, Silva AG. Distribuição espaço-temporal e dieta de Hoplosternum littorale (Hancock, 1828) (Siluriforme, Callichthyidae) no Rio da Draga, Vila Velha, ES. [on line]. 2007; 5(2):96-101. (Acceso agosto 22 de 2012). URL disponible en: http://www. naturezaonline.com.br/natureza/conteudo/ pdf/07_CaldeiraFN_etal_96101.pdf

10. Doro Abdallah V, Kozlowiski Azevedo R, Luis Luque J. Ecologia da comunidade de metazoários parasitos de tamboatá Hoplosternum littorale (Hancock, 1828) (Siluriformes, Callichthyidae) do rio Guandu, Estado do Rio de Janeiro, Brasil. Acta Sci Biol Sci 2006; 28(4):413-419.

11. Nilin J, Castro CB de, Pimentel MF, FranklinJúnior W, Matos RFG, Lotufo TMC, CostaLotufo LV. Water toxicity assessment of the Ceará River Estuary (Brazil). J Braz Soc Ecotoxicol 2007; 2(2):107-113.

12. Araújo JC. Assoreamento em reservatórios do semi-árido: modelagem e validação. Rev Bras Rec Hid 2003; 8(2):39-56.

13. Becker H, Farias DBA, Silva R. Açude Santo Anastácio: um estudo de caso. En: Oliveira SJM, Silva EV, Seabra G, Rodriguez JMM. (Org.). Gestão dos recursos hídricos e planejamento. (1aEd.) João Pessoa, Brasil: Editora Universitária da Universidade Federal da Paraíba; 2010.

14. Zar JH. Bioestatistical analysis. 5a ed. 957p. New Jersey: Prentice-Hall; 2010.

15. Segatti Hahn N, Lescano de Almeida VL, Gaspar da Luz KD. Alimentação e ciclo alimentar diário de Hoplosternum littorale (Hancock) (Siluriformes, Callichthyidae) nas lagoas Guaraná e Patos, da planície do alto rio Paraná, Brasil. Rev Bras Zool 1997; 14(1):57-64.

16. Lima-Junior SE, Goitein R. Fator de condição e ciclo gonadal de fêmeas de Pimelodus maculatus (Osteichthyes, Pimelodidae) no rio Piracicaba (SP, Brasil). B Inst Pesca 2006; 32(1):87-94.
17. Oliva-Paterna FJ, Torralva M, Carvalho ED. Length-weight relantionship for 20 species collected in the Jurumirim reservoir (Paranapanema Basin, Brazil). J Appl Ichthyol 2009; 25:360-361.

18. Machado-Allison AJ, Zaret TM. Datos sobre la biologia reproductiva de Hoplosternum littorale (Siluriformes-Callichthyidae) de Venezuela. Acta Cien Venez 1984; 35:142144.

19. Oliveira MA, Gurgel JJS. Exame biológico pesqueiro do Açude "Santo Anastácio", Fortaleza, Ceará, Brasil. Ciênc Agron 1977; 7(1-2):135-141.

20. Fausto-Filho J. Aspectos bioecológicos do açude Santo Anastácio do campus do Pici da Universidade Federal do Ceará. Ciênc Agron 1988; 19(2): 79-84.

21. Jucá-Chagas R, Boccardo L. The air-breathing cycle of Hoplosternum littorale (Hancock, 1828) (Siluriformes: Callichthyidae). Neotrop Ichthyol 2006; 4(3):371-373.

22. Winemiller KO. Feeding and reproductive biology of the currito, Hoplosternum littorale, in the Venezual Ilanos with comments on the possible function of enlarged male pectoral spines. Environ Biol Fishes 1987; 20(3):219-227.

23. Marcelo Aranha JM, Caramaschi EP, Caramaschi U. Ocupação espacial, alimentação e época reprodutiva de duas espécies de Corydoras Lacépède (Siluroidei, Callichthyidae) coexistentes no rio Alambari (Botucatu, São Paulo). Rev Bras Zool 1993; 10(3):453-466.

24. Araujo RB, Garutti V. Biologia reprodutiva de Aspidoras fuscoguttatus (Siluriformes, Callichthyidae) em riacho de cabeceira da bacia do alto rio Paraná. Iheringia Sér Zool 2002; 92(4):89-98.

25. Godinho HP, Godinho AL. Águas, peixes e pescadores do São Francisco das Minas Gerais. ( $1^{a}$ Ed.) Minas Gerais, Brasil: Editora PUC Minas; 2003. 